\title{
THE GRUNTS (FAMILY HAEMULIDAE) OF THE SPERMONDE ARCHIPELAGO, SOUTH SULAWESI
}

\author{
Andi Iqbal Burhanuddin ${ }^{1}$ and Yukio Iwatsuki ${ }^{2}$ \\ ${ }^{1}$ Laboratory of Marine Biology, Faculty of Marine Science and Fisheries, Hasanuddin \\ University, Makassar. Email: iqbalburhanuddin@yahoo.com \\ ${ }^{2}$ Division of Fisheries Science, Faculty of Agriculture, Miyazaki Univ. Miyazaki, Japan
}

\begin{abstract}
Fish diversity monitoring could be utilized as a basis for formulating management regulation of the fisheries resources. This study was conducted to describe the grunt of the family Haemulidae from the Spermonde Archipelago, South Sulawesi. Specimens were collected in Rajawali and Paotere Fish Landing Port Makassar, South Sulawesi from August 2003 to November 2010. The results showed that there were thirteen species representing three genera of family Haemulidae inhabiting the area were examined and identified: Diagramma pictum (Thunberg, 1792), Plectorhinchus albovittatus (Rüppell, 1838), Plectorhinchus chaetodonoides Lacepède, 1801, Plectorhinchus chrysotaenia (Bleeker, 1855), Plectorhinchus flavomaculatus (Cuvier in Cuvier and Valenciennes, 1830), Plectorhinchus gibbosus Lacepède, 1802, Plectorhinchus lessonii (Cuvier in Cuvier and Valenciennes, 1830), Plectorhinchus lineatus (Linnaeus, 1758), Plectorhinchus picus (Cuvier in Cuvier and Valenciennes, 1830), Plectorhinchus polytaenia (Bleeker, 1852), Plectorhinchus vittatus (Linnaeus, 1758), Pomadasys argenteus (Forsskål, 1775), Pomadasys maculatus (Bloch, 1793). The local name available of each species was given.
\end{abstract}

Keywords: grunt, haemulidae, spermonde, south Sulawesi

\section{INTRODUCTION}

Haemulid fishes, commonly called the grunt, collectively known as sweetlips, include commercial fishes widely inhabiting inshore and offshore areas from tropical to temperate regions. Those families are mainly confined to the tropical of Indo-Pacific and West Africa. Gruntfishes are typical perch-like fishes, body oblong, moderately compressed, and covered with moderate or small ctenoid scales. Head and body usually silvery, grey, and light or reddish brown, frequently mottled, spotted or stripped with dusky, blue, red or yellow. They are epibenthic in habit and generally associated with rock formation or coral reefs where they lurk in or beneath ledges through at least most of the daytime hours (Allen, 2000; Araya, 2002; Randal and Myers, 1993). They 
usually occur solitary or in small groups and form large aggregations while spawning. Their diet consists of small fishes and variety of invertebrates including polychaete worm, crab, shrimp, squid, octopus, and starfish and caught primarily by handline, traps, and trawls (Allen, 2000).

The gruntfishes in the South Sulawesi region were collected and reported by Iwatsuki et al. (2000). However, their report did not correspond well with species descriptions. The commercial fishes in some publications were collected from Java Island, Sumatera Islands and Maluku Islands. The result of this work will be used as basis for further study especially on bio-diversity monitoring and would hopefully be utilized as a basis for formulating management regulation of the fisheries resources for the Spermonde Archipelago, South Sulawesi.

\section{METHOD}

Specimens of Gruntfishes were collected from August 2003 to November 2010 in Rajawali Fish Landing Port and Paotere Fish Landing Port, South Sulawesi. The specimens purchased had been collected mostly by hand-line from Makassar Strait, South Sulawesi. The specimens were examined at the Laboratory of Marine Biology, Faculty of Marine Science and Fisheries, Hasanuddin University,
Makassar. Counts and measurement were as prescribed by Hubbs and Lagler (1958). Identification was based on Rau \& Rau (1980), Allen (2000) and Carpenter (2001).

\section{RESULTS AND DISCUSSION}

\subsection{Diagnostic Features of the Family Haemulidae}

The Haemulidae with the following combination of characters: Small to moderate-size fishes. Typical perch-like fishes, body oblong, moderately compressed, and covered with moderate or small ctenoid scales; pelvic fin axillary scales well developed. Mouth terminal moderate to large, extending somewhat when opened, with relatively thick lips, strong canines at front of jaws; either conical or molariform teeth on sides of jaws; not teeth on roof of mouth. Dorsal fin continuous with a notch, containing $\mathrm{X}$ spines and 9 or 10 soft rays; anal fin with III, 8-10; pectoral fin with 13-15 soft rays; pelvic fin, with I spine and 5 soft rays; caudal fin emarginated to forked. Head and body silvery, grey, and light or reddish brown, frequently mottled, spotted or stripped with dusky, blue, red or yellow. Red markings on or near base of pectoral fins, on pelvic-, anal-, and dorsal-fin membranes near base of fins, on opercular and preopercular margins, and on head, these markings often variable within species. 


\subsubsection{Diagramma pictum (Thunberg, 1792) (Fig. A.1)}

Descriptions:

English: Painted sweetlips

Indonesian: Gajih

D IX-X,22-23; A III,7-8; P 17. Body oblong, compressed. Lips fleshy, moderately swollen with age. Chin with 6 pores but no median pit. Lower jaw without longitudinal groove at middle. Total gill rakers on first gill arch 19 to 23 (6 to 8 on upper limb, 1 at corner, and 13 to 16 on lower limb). Scales ctenoid (rough to touch). Lateral line with about 54 to 73 tubed scales.

Colour: adults blue-grey with bright yellow to golden orange spots sometimes forming lines on head; inside mouth bright orange to red; dorsal fins bordered with black; anal and pelvic fins tipped with black; juveniles dark brown to black above, divided into 3 or more broad longitudinal stripes by narrower pearl blue interspaces; silvery yellow below; dorsal and caudal fins yellow with black patches and broken stripes; stripes increase with age and break up into small rounded spots before fading on body and sometimes on caudal fin.

Size: Maximum total length about $100 \mathrm{~cm}$, commonly to $45 \mathrm{~cm}$.

\subsubsection{Plectorhinchus albovittatus (Rüppell, 1838) (Fig. A. 2)}

Descriptions:

English: Giant sweetlips

Indonesian: Kompele mas
D XII-XIII,16-20; A III,7; P 17. Body oblong, compressed Lips fleshy, greatly swollen with age. Chin with 6 pores but no median pit. Total gill rakers on first gill arch 26 to 31 (6 to 9 on upper limb, 1 at corner, and 19 to 21 on lower limb). Scales ctenoid (rough to touch). Lateral line with about 54 to 56 tubed scales.

Colour: juveniles brown, paler below, with 3 narrow white bands on body descending down nape and snout; spinous dorsal pale brown or cream, with a narrow dark brown edge, rayed dorsal fin dark brown with a whitish horizontal stripe and a narrower one above, both reaching posterior margin of fin, last 2 or 3 short rays white, with the posterior half ray usually dark brown; caudal fin dark brown below, white above, with tips dark brown to black-brown and a dark brown bar diagonally across upper lobe; anal fin dark brown, posterior rays light brown; pectoral fins hyaline to very pale brown; pelvic fins tipped with dusky brown. Adults grey to grey-brown with pectoral, pelvic, and anal fins blackish, lower lobe and upper tip of caudal fin black, anterior half of soft dorsal fin black, spinous dorsal fin dusky to black; lower lip and chin white; belly silvery grey to white.

Size: Maximum total length about $120 \mathrm{~cm}$, commonly to $80 \mathrm{~cm}$.

\subsubsection{Plectorhinchus chaetodonoides Lacepède, 1801 (Fig. A.3) \\ Descriptions: \\ English: Harlequin}


Indonesian: Kaci macan

D XI-XII,18-20; A III,7-8; P 16-17. Body oblong, compressed. Lips fleshy, moderately swollen with age. Chin with 6 pores but no median pit. Total gill rakers on first gill arch 36 to 43 (9 to 12 on upper limb, 1 at corner, and 27 to 32 on lower limb). height of soft part of dorsal fin about equal to length of its base. Scales ctenoid (rough to touch). Lateral line with about 52 to 59 tubed scales.

Colour: juveniles brownish with large, well-defined creamy white blotches on body that include brown spots with age; colour gradually changing into a greyish background with large, deep brown spots.

Size: Maximum total length about $65 \mathrm{~cm}$; commonly to $40 \mathrm{~cm}$.

\subsubsection{Plectorhinchus chrysotaenia (Bleeker, 1855) (Fig. A. 4)}

Descriptions:

English: Goldbanded sweetlips

D XIII,18-21; A III,7-8; P 16-17. Body oblong, compressed. Lips fleshy, moderately swollen with age. Chin with 6 pores but no median pit. Total gill rakers on first gill arch 28 to 33 (9 to 12 on upper limb, 1 at corner, and 18 to 21 on lower limb). Scales ctenoid (rough to touch). Lateral line with about 53 to 58 tubed scales.

Colour: body and head bright blue-green to sky blue with 5 to 7 bright yellow longitudinal bands often separated by thinner yellow bands or lines of spots; fins bright yellow to orange; juveniles similar to adults, but with fewer bands

Size: Maximum total length about $51 \mathrm{~cm}$, commonly to $40 \mathrm{~cm}$.

\subsubsection{Plectorhinchus flavomaculatus (Cuvier in Cuvier and Valenciennes, 1830) (Fig.A. 5)}

\section{Descriptions:}

English: Lemon sweetlips

D XII or XIII,19-22; A III,7-8; P 16-17. Body oblong, compressed. Lips fleshy moderately swollen with age. Chin with 6 pores but no median pit. Total gill rakers on first gill arch 26 to 34 (11 to 14 on upper limb, 1 at corner, and 16 to 19 on lower limb). Scales ctenoid (rough to touch). Lateral line with about 53 to 60 tubed scales.

Colour: bluish grey, juveniles with golden or rusty orange stripes along the body that break into a reticulate pattern and later form small spots that may be lost with age or remain as lines, or lines of spots on head.

Size: Maximum total length about $72 \mathrm{~cm}$, commonly to $40 \mathrm{~cm}$.

\subsubsection{Plectorhinchus gibbosus}

\section{Lacepède, 1802 (Fig. A. 6)}

Descriptions:

English: Harry hotlips

D XIII-XIV,15-17; A III,7-8; $\mathrm{P}_{1}$ 16-18. Body oblong, compressed. Lips fleshy, greatly swollen with age. Chin with 6 pores but no median pit. Total gill rakers on first gill arch 24 to 30 (8 to 10 on upper limb, 1 at corner, and 17 to 19 on lower limb). 
Scales ctenoid (rough to touch). Lateral line with about 46 to 55 tubed scales.

Colour: juveniles brownish, caudal fin pink or transparent; adults uniform dark grey to brownish or blackish; large examples are sometimes mottled with light brown.

Size: Maximum total length about $75 \mathrm{~cm}$, commonly to $45 \mathrm{~cm}$.

\subsubsection{Plectorhinchus lessonii (Cuvier in Cuvier and Valenciennes, 1830) (Fig. A. 7)}

Descriptions:

English: Lesson's sweetlips

Indonesian: Raja bau

D XII-XIII,19-20; A III,7-8; P 16-18. Body oblong, compressed. Lips fleshy, moderately swollen with age. Chin with 6 pores but no median pit. Total gill rakers on first gill arch 19 to 22 (5 to 7 on upper limb, 1 at corner, and 11 to 15 on lower limb). Scales ctenoid (rough to touch). Lateral line with about 54 to 58 tubed scales.

Colour: juveniles dark brown with 2 white stripes on body and through caudal fin, increasing to 4; adult with about 4 brown stripes on body above pectoral fins and 2 brown stripes below eye on head, belly white; middle of pectoral fins black in juveniles, becoming colourless with base red-brown; pelvic fins pale with the anterior basal half of membranes black, becoming brown; dorsal, caudal, and anal fins yellow, spotted and margined with black.

Size: Maximum total length about $60 \mathrm{~cm}$, commonly to $40 \mathrm{~cm}$.

\subsubsection{Plectorhinchu lineatus (Linnaeus, 1758) (Fig. A. 8)}

\section{Descriptions:}

English: Lined sweetlips

Indonesian: Raja bau kuning D XIII,19-20; A III,7; P 17. Body oblong, compressed. Lips fleshy, moderately swollen with age. Chin with 6 pores but no median pit. Total gill rakers on first gill arch 26 to 30 (7 to 11 on upper limb, 1 at corner, and 17 to 19 on lower limb). Scales ctenoid (rough to touch). Lateral line with about 54 to 58 tubed scales.

Colour: juveniles with few horizontal to slightly oblique dark brown bands which subdivide with age until the body appears to be dark chocolate brown above, with a network of fine white lines running up and back, the broad brown bars breaking up into smaller and smaller spots on lower sides; belly white; lips and fins bright yellow, anal and caudal fins dotted with black; pectoral fins with a splash of bright crimson or scarlet red at the base.

Size: Maximum total length about $60 \mathrm{~cm}$, commonly to $40 \mathrm{~cm}$. 


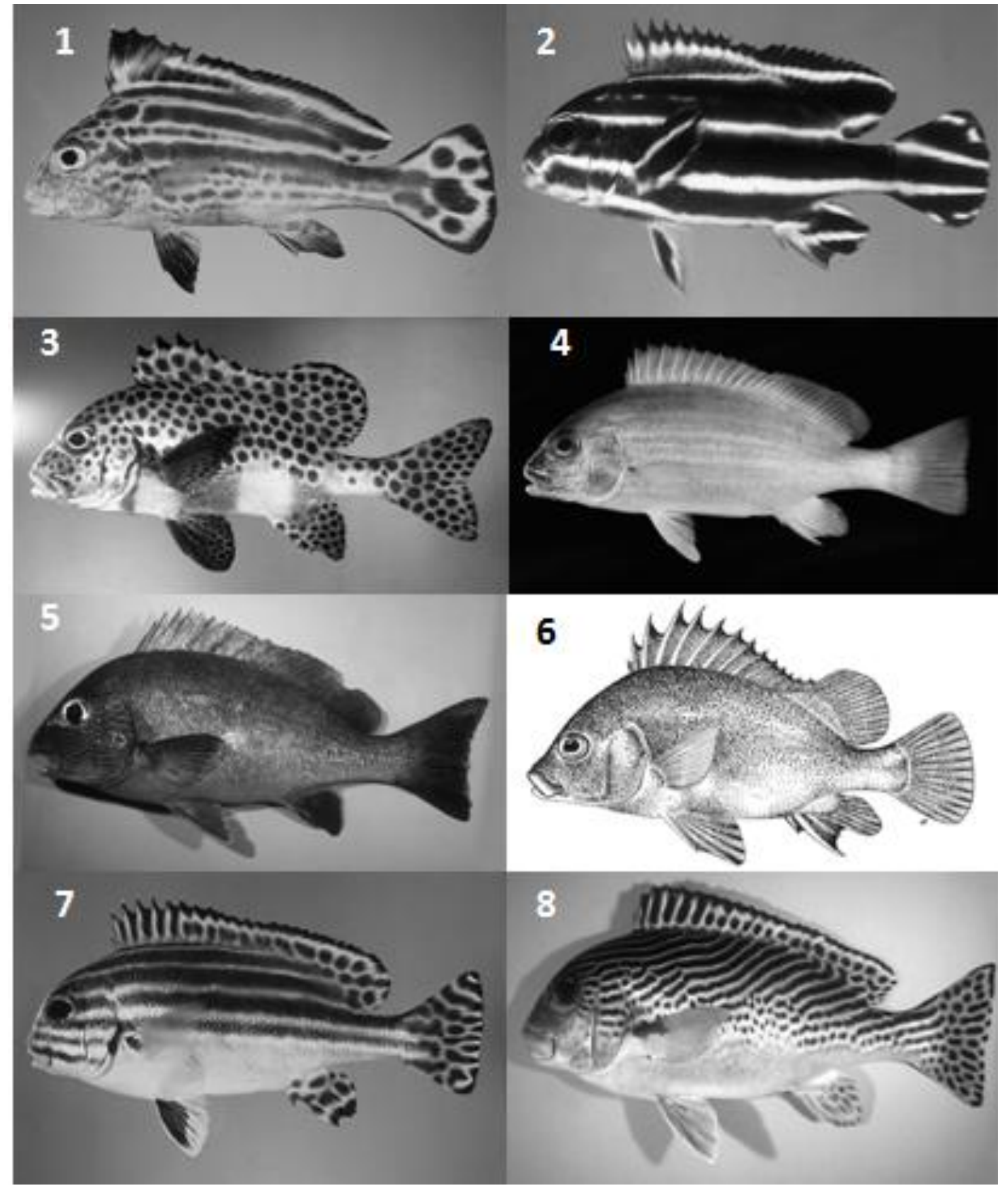

Figure A. 1) Diagramma pictum (Thunberg, 1792), 2) Plectorhinchus albovittatus (Rüppell, 1838), 3) Plectorhinchus chaetodonoides Lacepède, 1801, 4) Plectorhinchus chrysotaenia (Bleeker, 1855), 5) Plectorhinchus flavomaculatus (Cuvier in Cuvier and Valenciennes, 1830), 6) Plectorhinchus gibbosus Lacepède, 1802, 7) Plectorhinchus lessonii (Cuvier in Cuvier and Valenciennes, 1830), 8) Plectorhinchus lineatus (Linnaeus, 1758) (Pictures from Randall. JE and Carpenter, 2011) 


\subsubsection{Plectorhinchus picus (Cuvier in} Cuvier and Valenciennes, 1830) (Fig. B. 9)

\section{Descriptions:}

English: Spotted sweetlips

D XII,19-22; A III,7; P 17. Body oblong, compressed. Lips f leshy,greatly swollen with age. Chin with 6 pores but no median pit. Total gill rakers on first gill arch 33 to 37 (8 to 13 on upper limb, 1 at corner, and 22 to 26 on lower limb). Scales ctenoid (rough to touch). Lateral line with about 62 to 70 tubed scales.

Colour: Dorsal fin dark brown to blackish with a median horizontal grey stripe on membranes only and with a series of large black spots and sometimes with a narrow dark margin; pectoral and pelvic fins with the base and axil vermillion in some specimens; inside of mouth, hind edge of maxilla, gill-cover membrane and base of pectoral fins vermillion, scarlet, or red-brown; belly pale mauve grey.

Size: Maximum total length about $85 \mathrm{~cm}$, commonly to $60 \mathrm{~cm}$.

\subsubsection{Plectorhinchus polytaenia} (Bleeker, 1852) (Fig. B. 10)

\section{Descriptions:}

English: Ribboned sweetlips

D XII,19-22; A III,7; P 17. Body oblong, compressed. Lips fleshy, moderately swollen with age. Chin with 6 pores but no median pit. Total gill rakers on first gill arch 26 to 29 (7 to 9 on upper limb, 1 at corner, and 17 to 20 on lower limb). Scales ctenoid (rough to touch). Lateral line with about 54 to 60 tubed scales.

Colour: brown to yellowish grey with 5 to 9 fairly narrow grey or white longitudinal stripes outlined with dark brown on body and continuing around snout; fins yellow, soft dorsal, caudal, and pectoral fins with darker stripes disappearing with age; eye and lips yellowish; mouth, tongue, and gill rakers scarlet; chin white; juveniles have fins striped and fewer stripes on body.

Size: Maximum total length about $40 \mathrm{~cm}$, commonly to $30 \mathrm{~cm}$.

\subsubsection{Plectorhinchus vittatus (Linnaeus, 1758) (Fig. B.11)}

Descriptions:

English: Oriental sweetlips

D XII,17-20; A III,7; P 17. Body oblong, compressed. Lips fleshy, greatly swollen with age. Chin with 6 pores but no median pit. Total gill rakers on first gill arch 29 to 34 (9 to 11 on upper limb, 1 at corner, and 20 to 23 on lower limb). Scales ctenoid (rough to touch). Lateral line with about 55 to 65 tubed scales.

Colour: juveniles have connected black blotches and spots that gradually break up into horizontal stripes; pectoral fins black in juveniles becoming uniform yellow in adults; tail spotted with age. Adults with 6 to 12 broad dark brown, blue-brown or black stripes that persist on the belly and join horizontally across the nape and snout with anterior part of pale interspaces yellow forming 2 bright yellow stripes across interorbital and 2 around snout; eye usually yellow; fins yellow with black 
margins to vertical fins and black spots, body, dark blotches on dorsal fin and pectoral fins uniform yellow with numerous scattered dark brown to blackish red-brown, chocolate, or blackish base, spots on body.

pelvic fins yellow with base red-brown, Size: Maximum total length about $60 \mathrm{~cm}$, scarlet, or dark brown. commonly to $40 \mathrm{~cm}$.

Size: Maximum total length about $60 \mathrm{~cm}$, commonly to $40 \mathrm{~cm}$.

\subsubsection{Pomadasys maculatus (Bloch, 1793) (Fig. B. 13)}

\subsubsection{Pomadasys argenteus (Forsskål, Descriptions:} 1775) (Fig. B. 12)

English: Saddle grunt

Descriptions:

English: Silver grunt

D XII,14; A III,7; P 17. Body depth 2.7 to 2.8 times in standard length. Head blunt, its upper profile convex; mouth small; maxilla reaching to eye; teeth in jaws arranged in villiform (brush-like) bands; 2 pores and a median pit on chin. Scales ctenoid (rough to touch); lateral line with 45 to 50 scales; 5 scales between lateral line and dorsal-fin origin; 21 or 22 scales around caudal peduncle, 9 above lateral line, 10 or 11 below. Swimbladder without anterior extensions.

Colour: juveniles with body pale brownish, lighter below, back with irregular longitudinal streaks on alternate scale rows; dorsal fin with dusky membranes; a dark spot on gill cover. Adults with silvery D XII,13-15; A III,6 or 8; P 17. Body depth 2.3 to 2.7 times in standard length. Head blunt, its upper profile convex; mouth small; maxilla reaching to eye; teeth in jaws arranged in villiform(brush-like) bands; 2 pores and a median pit on chin. Scales ctenoid (rough to touch); lateral line with 50 to 55 scales; 7 to 9 scales between lateral line and dorsal-fin origin; 22 to 25 scales around caudal peduncle, 9 or 10 above lateral line, 11 or 12 below.

Colour: silvery grey, head purplish or brownish, nape and back with a series of incomplete cross bars (one on nape most conspicuous); spinous part of dorsal fin with a large black blotch; dorsal and caudal fins edged with black, other fins yellowish. Size: Maximum total length about $50 \mathrm{~cm}$, commonly to $15 \mathrm{~cm}$. 

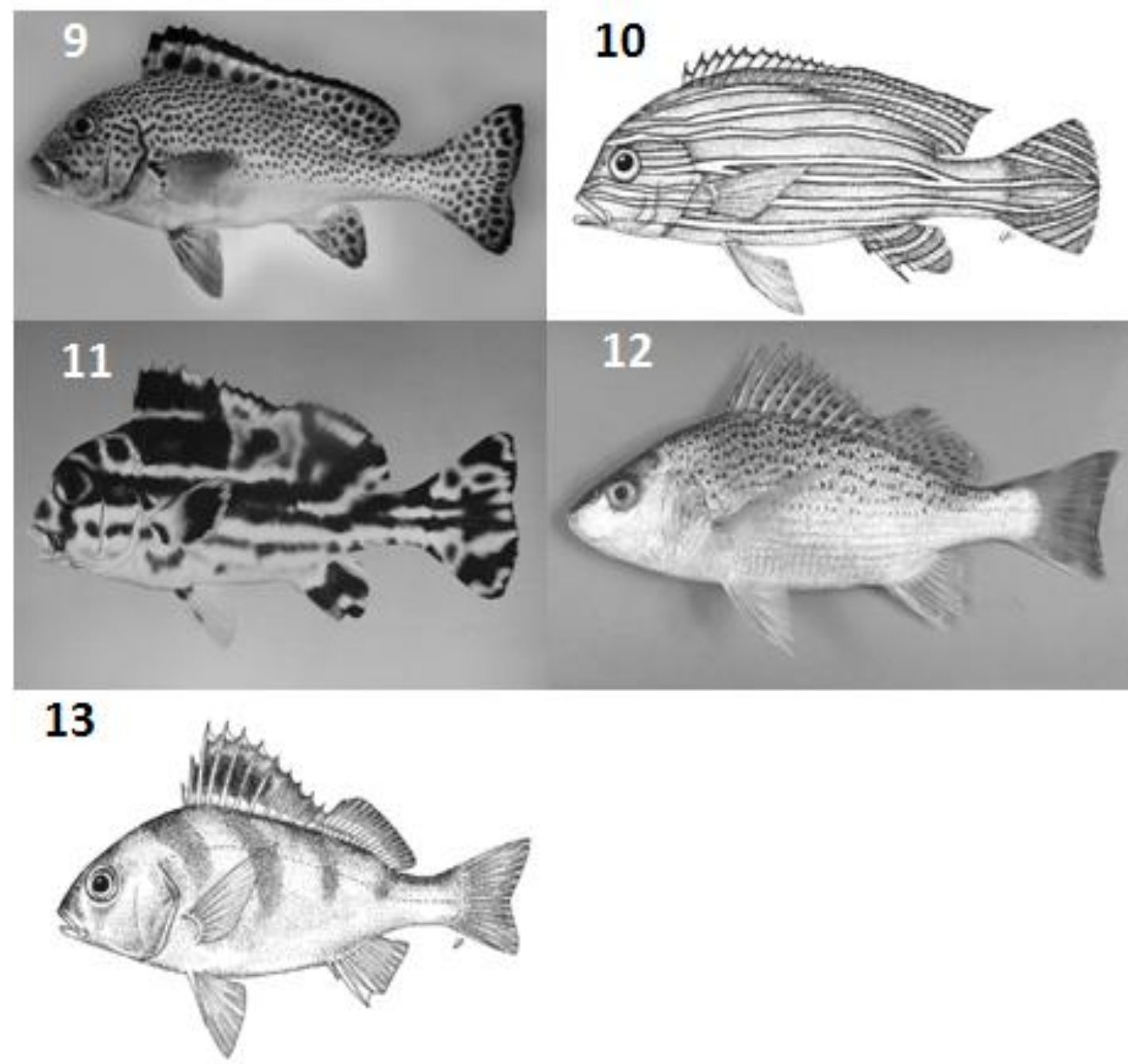

Figure B. 9) Plectorhinchus picus (Cuvier in Cuvier and Valenciennes, 1830), 10) Plectorhinchus polytaenia (Bleeker, 1852), 11) Plectorhinchus vittatus (Linnaeus, 1758), 12) Pomadasys argenteus (Forsskål, 1775), 13) Pomadasys maculatus (Bloch, 1793). (Pictures from Randall. JE and Carpenter, 2011)

\section{CONCLUSION}

Thirteen species representing three genera of the family Haemulidae were described and identified from the Spermonde Archipelago, South Sulawesi. Diagramma pictum (Thunberg, 1792), Plectorhinchus albovittatus (Rüppell, 1838), Plectorhinchus chaetodonoides
Lacepède, 1801, Plectorhinchus chrysotaenia (Bleeker, 1855), Plectorhinchus flavomaculatus (Cuvier in Cuvier and Valenciennes, 1830), Plectorhinchus gibbosus Lacepède, 1802, Plectorhinchus lessonii (Cuvier in Cuvier and Valenciennes, 1830), Plectorhinchus lineatus (Linnaeus, 1758), Plectorhinchus picus (Cuvier in Cuvier 
and Valenciennes, 1830), Plectorhinchus

polytaenia

(Bleeker,

1852),

Plectorhinchus vittatus (Linnaeus, 1758),

Pomadasys argenteus (Forsskål, 1775),

Pomadasys maculatus (Bloch, 1793).

The local name available of each species was give.

\section{REFERENCES}

Allen, G.R. and M. Adrim. 2003. Coral reef fishes of Indonesia. Zoological Studies, 42(1):1-72.

Allen, G.R. and M.V. Erdmann. 2006.

Pterocaesio flavifasciata, a new species of fusilier (Teleostei: Caesionidae) from Sumatra, Indonesia. Aqua. J. of Ichthyology and Aquatic Biology, 12(1):27-30.

Allen, G.R. and M.V. Erdmann. 2008. Pterocaesio monikae, a new species of fusilier (Caesionidae) from western New Guinea (Papua and Papua Barat provinces, Indonesia). Aqua. International J. of Ichthyology, 13(3-4):163-170.

Allen, G.R. 2000. Marine fishes of south-east Asia: a field guide for anglers and divers. Periplus Edition. Western Australia.

Arayama, K. 2002. Juvenile of the sweetlips, Plectorhinchus albovittatus (Haemulidae,
Perciformes), collected from Chiba prefecture, central Japan. I.O.P. Diving News, 13(6):2-5. [In Japanese. English abstract.]

Carpenter, K.E. 2001. Lethrinidae. FAO species identification guide for fishery purpose. Western Central Pacific. Vol. 5. FAO, Rome.

Hubbs, C.L., and K.F. Lagler. 1958. Fishes of the Great region. Bull Cranbrook Inst. Sci., 26:1-213.

Iwatsuki, Y., M.I. Djawad, A.I. Burhanuddin, H. Motomura, and K. Hidaka. 2000. A preliminary list of the epipelagic and inshore fishes of Makassar (=Ujung $\quad$ Pandang), South Sulawesi, Indonesia, collected mainly from fish market between 23-27 January 2000, with notes on fishery catch characteristics. Bull of the faculty of Agriculture, Miyazaki University, 47:95-114.

Rau, N. and A. Rau. 1980. Commercial fishes of the Philippines. German Agency for Technical Cooperation. Eschborn. 120-157pp.

Randal, J.E. and R.F. Myers. 1993. Parupeneus moffitti, a new goatfish (Perciformes: Mullidae) from the Mariana Island. Micronesia, 26:69-75. 